\title{
Fuel consumption and exhaust emissions in the process of mechanized timber extraction and transport
}

\author{
Piotr Lijewski $^{1} \cdot$ Jerzy Merkisz $^{1} \cdot$ Paweł Fuć $^{1} \cdot$ Andrzej Ziółkowski $^{1}$ \\ Lukasz Rymaniak $^{1}$ - Władysław Kusiak ${ }^{2}$
}

Received: 11 December 2015/Revised: 12 November 2016/ Accepted: 17 November 2016/Published online: 25 November 2016 (C) The Author(s) 2016. This article is published with open access at Springerlink.com

\begin{abstract}
The paper focuses on the determination of fuel consumption $\left(\mathrm{CO}_{2}\right.$ emission) and exhaust emissions such as $\mathrm{CO}, \mathrm{HC}, \mathrm{NO}_{\mathrm{x}}$, and $\mathrm{PM}$ in the process of timber extraction and transport. A complex assessment of fuel consumption and exhaust emissions was performed for the entire, fully mechanized supply chain including, tree felling, delimbing, and bucking with a harvester, timber extraction with a forwarder and transport with a truck. The performed investigations determined unit exhaust emissions (referred to $1 \mathrm{~m}^{3}$ of timber) for the entire technological process and its individual stages. The investigations of the exhaust emissions and fuel consumption were performed under actual conditions of typical forest operations and transport. State-of-the-art portable emissions measurement system equipment was used for the measurements. The fuel consumption was determined through the carbon balance method. The investigations were performed for the process of extraction and transport of pulpwood. The measurements were performed on location in the town of Bębnikąt near Poznań, in a pinewood forest, typical of this part of Europe. The analysis includes the transport of timber to the lumberyard on a distance of $31.4 \mathrm{~km}$. The total fuel consumption for the entire mechanized supply chain was $2.10 \mathrm{dm}^{3} / \mathrm{m}^{3}$. The total exhaust emissions,
\end{abstract}

Communicated by Eric R. Labelle.

Piotr Lijewski

piotr.lijewski@put.poznan.pl

1 Institute of Combustion Engine and Transport, Poznan University of Technology, ul. Piotrowo 3, 60-965 Poznan, Poland

2 Poznan University of Life Sciences, ul. Wojska Polskiego 38/42, 60-627 Poznan, Poland however, amounted to: $\mathrm{CO}-8.91 \mathrm{~g} / \mathrm{m}^{3}, \mathrm{HC}-1.19 \mathrm{~g} / \mathrm{m}^{3}$, $\mathrm{NO}_{\mathrm{x}}-45.32 \mathrm{~g} / \mathrm{m}^{3}, \mathrm{PM}-4.04 \mathrm{~g} / \mathrm{m}^{3}$.

Keywords Logging · Fuel consumption/ $\mathrm{CO}_{2}$ emission · Exhaust emissions - Measurement in real operating conditions

\section{Introduction}

Based on the results of meteorological observations, it is observable that the Earth's climate is undergoing certain changes (Räisänen et al. 2004). Technological advancement leads to an increase in the emission of greenhouse gases, $\mathrm{CO}_{2}$ in particular. One of the most important sources of this greenhouse gas is combustion engines used in transport, heavy machinery, and other equipment. Another aspect tightly related to the operation of combustion engines is exhaust emissions. Today, we know that exhaust components such as $\mathrm{CO}, \mathrm{HC}, \mathrm{NO}_{\mathrm{x}}$, and $\mathrm{PM}$ are hazardous to human health. In the report published in 2012 International Agency for Research of Cancer (IARC), one of the World Health Organization (WHO) agencies informed that exhaust gas from diesel engines causes cancer (Press Release 2012). Before the announcement, diesel exhaust gas was classified as probably carcinogenic. Upon analysis of the latest environmental research, the WHO scientists clearly stated that diesel exhaust gas is a cause of cancer (Kheifets 2012; Attfield et al. 2012; Silverman et al. 2012; Metz 2003; Vermeulen et al. 2014). White et al. (2010) in Report of EPA (Environmental Protection Agency) based on decades of research on humans and animals confirms that particulate matter is carcinogenic and significantly contributes to the development of cancer, lung cancer in particular (Environmental Protection Agency 2002). It is, 
thus, fully justified to perform any works related to the assessment and reduction of the exhaust emissions from engines, including those used in forestry. In the process of timber extraction, combustion of fuel is associated with commonly used machinery such as harvesters, forwarders, trucks, etc.

Timber logging in Poland amounts to 37 million $\mathrm{m}^{3}$ per annum (Anon 2013) approximately $20 \%$ of which is fully mechanized logging using harvesters and forwarders (Szpojda 2013). The share of harvesters in logging is growing, and one should expect this trend to continue in the coming years. Comparing the emission of key exhaust components one may observe that timber logging using harvesters is a more ecological solution than using handheld chainsaws (Lijewski et al. 2013). The advancement of the mechanization process is a result of the necessity to increase the efficiency and operating safety. In many European countries the share of mechanized logging technologies is significant and frequently reaches approximately 90\% (Sweden, Ireland, and Finland-Karjalainen et al. 2001).

One of the main anthropogenic factors hazardous to the forest ecosystems is pollution emitted to the atmosphere, including that generated by the engines of vehicles and machinery. Air, as the fundamental component of biosphere, is a carrier for a variety of contaminants in the form of gases, dust and aerosols. Undoubtedly, air, its quality and contamination, is to be treated as impactful on the forest ecosystem, but not only. Following De Vries et al. $(2000$, a), currently the main hazard factor in European forests, aside from climate conditions or extreme weather conditions, is the excess amount of nitrogen and sulfur compounds. It is noteworthy that combustion of fossil fuels generates greenhouse gases $\left(\mathrm{CO}_{2}, \mathrm{CH}_{4}\right)$ that, according to many hypotheses, facilitate a growth in the Earth temperature, hence, influence the climate change-one of the main factors impactful on the forest ecosystem. It is, thus justified to take up the problem of exhaust emissions during operation of forest machinery.

There are multiple publications related to the environmental aspects of logging. Many works are devoted to fuel consumption, energy efficiency and exhaust emissions. In literature, one can often find works discussing the determination of fuel consumption for the performed forest operations (Klvac and Skoupy 2009; Klvac et al. 2012; Nordfjell et al. 2003; Holzleitner and Kanzian 2011). There are many findings discussing the energy consumption of such operations (Lindholm and Berg 2005, 2010). Other research discusses the determination of the emission of $\mathrm{CO}_{2}$ (Berg and Karjalainen 2003; Dias et al. 2007; Engel and Wegener 2012; Oberscheider et al. 2013). The mentioned research findings include different methods and indexes characterizing the logging operations but the idea behind these indexes is, in general, the same. Irrespective of the fact whether the index directly describes fuel consumption, energy consumption or the emission of $\mathrm{CO}_{2}$, it still determines the energy consumption during field operations and subsequent transport. In the above-mentioned studies, the methods of fuel consumption also differ (it is either a direct parameter method of fuel tank top-up or it is a result of a measurement performed via the CAN bus of the machine).

Among publications related to the determination of emissions of GHG, mainly $\mathrm{CO}_{2}$, and other exhaust emissions $\left(\mathrm{CO}, \mathrm{HC}, \mathrm{NO}_{\mathrm{x}}\right.$, and $\left.\mathrm{PM}\right)$ during mechanized logging, there are no works based on direct measurements since such research possibilities surfaced only a few years ago. Most of the available publications on exhaust emissions are based on estimations. Engel and Wegener (2012) focused on the comparison of the emission of greenhouse gases for three different methods of logging and transport of timber and the emission of GHG $\left(\mathrm{CO}_{2}\right)$ was estimated based on data available in literature. Such an approach is not uncommon. Other researchers (Berg and Karjalainen 2003; Lindholm and Berg 2005; Dias et al. 2007) also very often use data available in the literature. Determination of GHG and exhaust emissions is very often performed based on the fuel consumption (Oberscheider et al. 2013; Klvac and Skoupy 2009) or based on the emissions determined in laboratory tests (Athanassiadis 2000).

Most frequently, the subject described in the publications is the fuel consumption $\left(\mathrm{CO}_{2}\right.$ emission) during mechanized logging and subsequent transport. The emission of $\mathrm{CO}_{2}$ from a harvester engine was studied by Athanassiadis (2000). The investigations described by this author focused on the comparison of the exhaust emissions for diesel fuel and RME (rapeseed methyl esters). The problem of greenhouse gases during logging operations was also described in the works of Berg and Karjalainen (2003), Karjalainen and Asikainen (1996). In these papers, the fuel consumption and $\mathrm{CO}_{2}$ emission of a harvester were compared during logging and a wide variety of silvicultural treatments in Sweden and Finland such as: felling, extraction, transport of timber as well as operations in the stand establishment and those related to forest improvement work. A similar scope of works has been described by Berg and Lindholm (2005) and Dias et al. (2007). Interesting research results of a comparative nature have been presented in Engel and Wegener (2012). The subject of the analysis was the emission of GHG for different methods of logging and transport of timber. The fuel consumption in the transport phase was the subject of research and analyses conducted by Holzleitner and Kanzian (2011). The research described by these authors covered the analysis of transport of timber by a truck on different distances in a selected region of Austria. Another example of analyses of 
fuel consumption during transport of timber is investigations described by Lindholm and Berg (2005). In this work they compare the energy consumption of a complete transport system (i.e., well-to-wheel efficiency) for different means of transport, including vehicles fueled with alternative fuels. Analyses of fuel consumption and exhaust emissions were also performed by Nordfjell et al. (2003) and Klvac et al. (2012). In these works, the fuel consumption and emission of $\mathrm{CO}_{2}$ was compared for logging using a forwarder and a cable system. What is characteristic of the said publications is that beside the analysis of fuel consumption and exhaust emissions the authors also analyzed the logging efficiency (Berg and Karjalainen 2003; Dias et al. 2007; Johansson 1996; Nordfjell et al. 2003). The efficiency of forest operations is an issue tightly related to the energy consumption of these operations and exhaust emissions, which is why it is fully justified to consider these issues at the same time.

A common feature of most of the publications describing the exhaust emissions is the use of indirect methods that in fact are more like estimations. The investigations described in this paper significantly differ from those described in literature, because for the determination of the exhaust emissions and fuel consumption the authors used a PEMS analyzer (portable emission measurement system). World literature does not provide results of such works. The use of the PEMS equipment enables a direct measurement of the exhaust emissions under actual conditions of operation of machinery and vehicles. For the assessment of environmental performance of vehicles and machines, tests under actual conditions of operation are of paramount importance. Only then, can we obtain full information on real exhaust emissions and fuel consumption. A downside of such a type of research is the high cost of the measurement equipment and the need to adapt the vehicle to the tests. The obtained results, however, are reliable and unobtainable in laboratories on engine/chassis dynamometers. Today, the PEMS measurements are applied increasingly (Giannelli et al. 2010; Karim 2013; Merkisz et al. 2014; Lee 2013). The evolution of the legislation aims at a wider introduction of this type of measurements in the homologation procedures of engines, vehicles and machines. Because of the potential and research possibilities (actual conditions of operation), these measurements become increasingly important and in the future they will become some of the main methods of vehicle testing in terms of emissions and fuel consumption. It is noteworthy that tests performed under actual conditions of operation are becoming significant as they are the only method of a true validation of the actual exhaust emissions and fuel consumption.

The main aim of the paper is determining the exhaust emissions and fuel consumption for individual stages of mechanized timber extraction. An additional aim was establishing of the usefulness of the PEMS method in testing forest machinery.

\section{Materials and methods}

The exhaust emissions tests were performed for the process of logging and transport of timber (pulpwood of the length of $2 \mathrm{~m}$ ). The investigated extraction area was approx. 6 ha while the tests were performed on an area of approximately 2 ha. The measurement included a complete supply chain, from tree felling to transport of timber to the lumberyard. The tests were performed on a harvester, forwarder and a truck. The basic data of the vehicles and engines are shown in Table 1. The measurements of the exhaust emissions $\left(\mathrm{CO}_{2}, \mathrm{CO}, \mathrm{HC}, \mathrm{NO}_{\mathrm{x}}\right.$ and $\left.\mathrm{PM}\right)$ were performed under actual conditions of operation of the machinery in the forest. The tests were performed in the moderately humid coniferous forest located on a flat terrain on spodic soils. The measurements were carried out in the town of Bębnikat (Wielkopolska) in a pinewood forest, typical of Poland and this region of Europe.

The first tested machine was a harvester (John Deere $1270 \mathrm{E}$ ) that was used in tree felling, delimbing, and processing of the delimbed stems into assortments. The trees were felled at their rotation age: The tree age was 98 years, whose diameter at the cutting point was $20-40 \mathrm{~cm}$. Based on the measurement, the authors determined that the harvester had covered a total distance of $2.3 \mathrm{~km}$ during the tree cutting process. The second stage of the research was the measurements of exhaust emissions from the forwarder John Deere 1210E engine of a load rate of 13.0 tons while extracting the logs and forming the stack. The average extraction distance was $400 \mathrm{~m}$, and the average speed of the forwarder was $7 \mathrm{~km} / \mathrm{h}$. The emission measurements on the harvester and the forwarder took approximately $3 \mathrm{~h}$. In this time, the harvester processed $65 \mathrm{~m}^{3}$ of timber and the forwarder completed three full transport cycles. During each transport cycle about $9 \mathrm{~m}^{3}$ of timber was transported. The last stage was measurements performed on the engine of a truck transporting timber from the forest to the lumberyard. The tested vehicle was MAN TGA. This stage included the loading process, the trip to the destination (31.4 km, 3.8 of which was an unpaved road-0.38 h, and 27.6 was a paved one- $-0.66 \mathrm{~h}$ ), and the unloading process. The measurement was performed on a loaded vehicle for one direction of the test run only. The average speed of the truck in the forest was $10 \mathrm{~km} / \mathrm{h}$ and on the paved road $42 \mathrm{~km} / \mathrm{h}$. The trajectories of the forwarder and the truck were determined by the GPS system. The measurements were performed for two trips, each lasting approximately $2 \mathrm{~h}$ including loading. In these runs, 26.4 and $25.2 \mathrm{~m}^{3}$ of 
Table 1 Specifications of the investigated engines

\begin{tabular}{llllll}
\hline & $\begin{array}{l}\text { Capacity/number of } \\
\text { cylinders }\end{array}$ & $\begin{array}{l}\text { Maximum power output } \\
(\mathrm{kW})\end{array}$ & $\begin{array}{l}\text { Maximum torque } \\
(\mathrm{Nm})\end{array}$ & $\begin{array}{l}\text { Emission } \\
\text { regulation }\end{array}$ & $\begin{array}{l}\text { Mileage/operation } \\
\text { time }\end{array}$ \\
\hline Harvester & $9 \mathrm{dm}^{3} / 6$ in line & $170 @ 1900 \mathrm{rpm}$ & $1125 @ 1200-1400 \mathrm{rpm}$ & Stage IIIA/Tier 3 & $\sim 500 \mathrm{~h}$ \\
Forwarder & $6.8 \mathrm{dm}^{3} / 6$ in line & $136 @ 1900 \mathrm{rpm}$ & $780 @ 1400 \mathrm{rpm}$ & Stage IIIA/Tier 3 & $\sim 500 \mathrm{~h}$ \\
Truck & $10.5 \mathrm{dm}^{3} / 6$ in line & $324 @ 1900 \mathrm{rpm}$ & $2100 @ 1000-1400 \mathrm{rpm}$ & Euro IV & $39,000 \mathrm{~km}$ \\
\hline
\end{tabular}

timber was transported. The machines adapted and ready for the tests are shown in Fig. 1.

The fuel consumption was determined through the carbon balance method according to the procedure adopted by EPA. This method is commonly accepted worldwide as the most accurate method determining the fuel consumption. In this method, the fuel consumption is calculated based on the emission of $\mathrm{CO}_{2}$. The combustion of $1 \mathrm{~kg}$ of diesel fuel generates $2.77 \mathrm{~kg} \mathrm{CO}$. In the investigations, the authors measured the exhaust gas mass flow $(\mathrm{kg} / \mathrm{h})$ and $\mathrm{CO}_{2}$ concentration on the basis of which the mass of the generated $\mathrm{CO}_{2}$ was obtained.

The exhaust emissions measurements were carried out with a portable analyzer (Semtech DS by Sensors Inc.) It measures the concentration of exhaust components and the mass flow of exhaust gas and, at the same time, records the engine parameters. The entire volume of the exhaust gas is directed to the mass flow meter, and through a heated line $\left(191^{\circ} \mathrm{C}\right)$, a sample of the exhaust gas is fed to the analyzer. The exhaust gas is then filtered, and the concentration of the exhaust components is measured. The measurement of the concentrations of $\mathrm{CO}_{2}$ and $\mathrm{CO}$ is done with the non-dispersive method using an infrared analyzer NDIR (non-dispersive infrared), while $\mathrm{HC}$ is measured with FID (flame ionization detector). Subsequently, the exhaust gas is chilled to the temperature of $4{ }^{\circ} \mathrm{C}$, and the concentration of $\mathrm{NO}_{\mathrm{x}}$ is measured in the non-dispersive analyzer using ultraviolet (NDUV-nondispersive ultraviolet). Together with the measurement data, the system records engine and vehicle parameters (engine speed, engine load, coolant temperature, etc.) from the diagnostic and GPS systems. For the measurement of the particulate matter, Semtech LAM (Laser Aerosol Monitor) by Sensors Inc. was applied. This analyzer uses laser light dispersion by the gas particles. Semtech LAM determines the real-time concentration of PM in the exhaust gas. It can be used as a stationary analyzer or a portable one (for actual traffic operation).

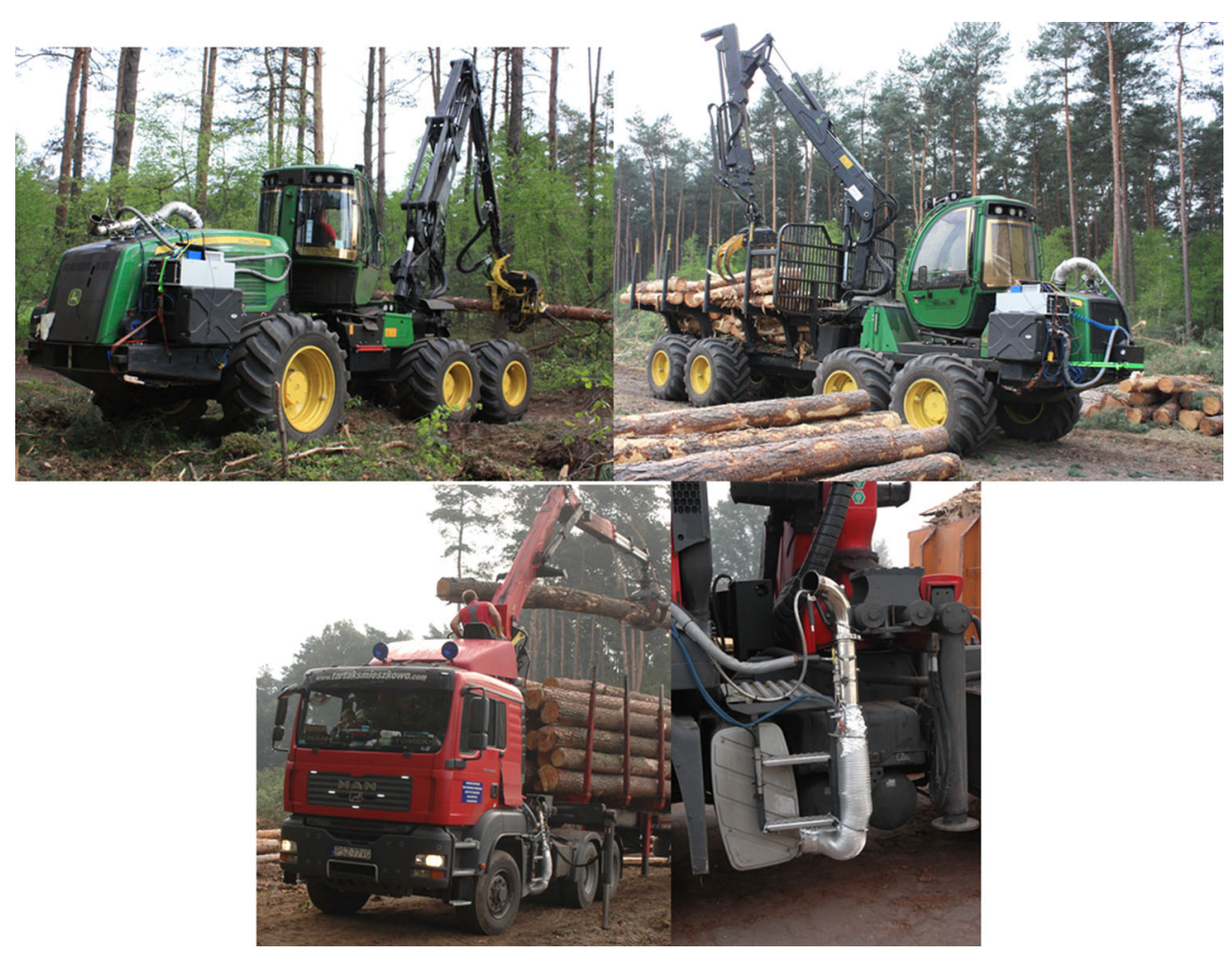

Fig. 1 Forest machinery and measurement equipment during the measurements 
The investigations determined the unit fuel consumption and unit emission of $\mathrm{CO}_{2}$, i.e., referred to $1 \mathrm{~m}^{3}$ of obtained timber. The authors decided on such an interpretation of the results because it is of a much more universal nature compared to the results referred to the unit of time. The proposed assessment of fuel consumption contains information on the efficiency of performed works where efficiency is construed as energy needed to obtain a unit result. In the analyzed case the result was $1 \mathrm{~m}^{3}$ of timber.

\section{Results and discussion}

It is to be stressed that efficiency depends on a variety of factors, e.g., type of timber (size of the logs-diameter and length), terrain conditions, machine operator skills, ambient conditions as well as the machine used and its technical condition. Hence, the results presented in the paper pertain to an individual specified case. The used method allows considering these factors in the investigations. The aim of the research, however, was different and focused on the assessment of the energy demand for the entire technological process of logging based on a new method not yet applied in investigations on forest machinery. Analyses including the influence of the above-mentioned factors will be a subject of future research.

The fuel consumption and $\mathrm{CO}_{2}$ emission in individual stages of the process are shown in Table 2. The table shows that the most energy demanding stage was the tree felling, logging, and maneuvering performed by the harvester, while the least demanding was the work performed by the forwarder. The share of the fuel consumption of the harvester in the entire technological cycle was $38 \%$, while the transport to the lumberyard constituted $35 \%$ of the fuel consumption (Fig. 2). The transport of timber from the stand to a landing with the forwarder was $27 \%$ of the fuel consumption of the entire cycle. The authors also performed an analysis of energy consumption of individual stages of operation of the forwarder and observed that the greatest fuel consumption (as much as 53\%) is generated by timber loading and maneuvering, and the smallest fuel consumption, by transport. Nordfjell et al. (2003) has

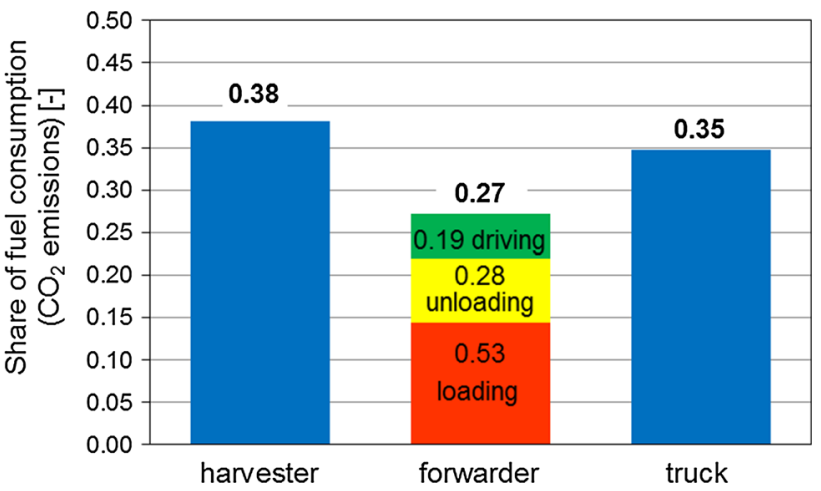

Fig. 2 Shares of fuel consumption/emission of $\mathrm{CO}_{2}$ of machines and the truck in the timber extraction process

observed similar proportions for 20 and 21 ton forwarders as well as for the loading of sawlogs.

The fuel consumption for the entire technological process was $2.10 \mathrm{dm}^{3} / \mathrm{m}^{3}\left(2112 \mathrm{~g} \mathrm{CO}_{2} / \mathrm{m}^{3}\right)$. This result is difficult to compare with other works because there are no publications on comprehensive measurements covering the entire process from tree felling to transport to the lumberyard. The authors decided to scrutinize individual stages of the process, analogically to the used machinery: harvester, forwarder, and truck. In the described research, the harvester used $0.80 \mathrm{dm}^{3} / \mathrm{m}^{3}$ of fuel, which generated $\mathrm{CO}_{2}$ in the amount of $2112 \mathrm{~g} / \mathrm{m}^{3}$. The harvester fuel consumption results described by other authors differ from those presented in this paper. Athanassiadis (2000) has observed the fuel consumption of $1.14 \mathrm{dm}^{3} / \mathrm{m}^{3}\left(\mathrm{CO}_{2} 3030 \mathrm{~g} / \mathrm{m}^{3}\right)$. A greater fuel consumption for the harvester has also been observed by Klvac et al. (2003) $-1.32 \mathrm{dm}^{3} / \mathrm{m}^{3}$ and Dias et al. (2007) - 3215 (eucalypt stands) and $2315 \mathrm{~g} \mathrm{CO}_{2} / \mathrm{m}^{3}$ (maritime pine stands). Another example is the investigations described by Karjalainen and Asikainen (1996), who measured the emission of $\mathrm{CO}_{2}$ from the harvester $(1857 \mathrm{~g} /$ $\mathrm{m}^{3}$ ). This emission was lower than the one stated in this paper. For comparison with other works, hourly fuel consumption has also been considered according to Berg and Karjalainen (2003). For the harvester, it falls in the range between 12 and $16.5 \mathrm{dm}^{3} / \mathrm{h}$, while in the measurements described in this paper the authors obtained a value of
Table 2 Fuel consumption and $\mathrm{CO}_{2}$ emission for individual stages of extraction of $1 \mathrm{~m}^{3}$ of timber

\begin{tabular}{llc}
\hline & Fuel consumption $\left(\mathrm{dm}^{3} / \mathrm{m}^{3)}\right.$ & $\mathrm{CO}_{2}$ emissions $\left(\mathrm{g} / \mathrm{m}^{3}\right)$ \\
\hline Harvester & 0.80 & 2112 \\
Forwarder (total) & 0.57 & 1505 \\
Loading & 0.30 & 798 \\
Driving & 0.16 & 421 \\
Unloading & 0.11 & 286 \\
Road transport & 0.73 & 1936 \\
Total & 2.10 & 5553 \\
\hline
\end{tabular}


Table 3 Exhaust emissions for individual timber extraction stages for $1 \mathrm{~m}^{3}$ of timber

\begin{tabular}{lllll}
\hline & $\mathrm{CO}\left(\mathrm{g} / \mathrm{m}^{3}\right)$ & $\mathrm{HC}\left(\mathrm{g} / \mathrm{m}^{3}\right)$ & $\mathrm{NO}_{\mathrm{x}}\left(\mathrm{g} / \mathrm{m}^{3}\right)$ & $\mathrm{PM}\left(\mathrm{g} / \mathrm{m}^{3}\right)$ \\
\hline Harvester & 2.11 & 0.23 & 23.31 & 2.12 \\
Forwarder (total) & 3.38 & 0.29 & 15.22 & 1.02 \\
Loading & 1.98 & 0.14 & 8.43 & 0.47 \\
Driving & 0.87 & 0.70 & 3.62 & 0.27 \\
Unloading & 0.53 & 0.80 & 3.17 & 0.28 \\
Road transport & 3.42 & 0.67 & 6.79 & 0.94 \\
Total & 8.91 & 1.19 & 45.32 & 4.08 \\
\hline
\end{tabular}

$17.4 \mathrm{dm}^{3} / \mathrm{h}$. In majority of the listed results, the fuel consumption (emission of $\mathrm{CO}_{2}$ ) was similar compared to the ones described in this paper.

For the forwarder and the truck, the fuel consumption depends mainly on the covered distance, as well as on other factors travel speed, road surface conditions, etc. This factor is decisive in the analysis of fuel consumption and exhaust emissions. In the presented forwarder investigations, the observed fuel consumption was $0.57 \mathrm{dm}^{3} / \mathrm{m}^{3}$ $\left(1505 \mathrm{~g} \mathrm{CO}_{2} / \mathrm{m}^{3}\right)$. In the publications of other researchers (Nordfjell et al. 2003), the fuel consumption by the forwarder for a similar distance (extraction distance $400 \mathrm{~m}$ ) was approximately 0.27 and $0.33 \mathrm{dm}^{3} / \mathrm{m}^{3}$ depending on the type of used machine. Berg and Karjalainen (2003) in their investigations of a forwarder have obtained the fuel consumption of $0.53 \mathrm{dm}^{3} / \mathrm{m}^{3}$ for the extraction in Finland and $1.03 \mathrm{dm}^{3} / \mathrm{m}^{3}$ for the extraction in Sweden. The investigations were carried out on forwarders of a load rate greater than $10 \mathrm{t}$. The authors claim that such a big difference results from varied extraction distances in Finland and Sweden.

During the transport stage from the cutting site to the lumberyard, the vehicle consumed $0.73 \mathrm{dm}^{3} / \mathrm{m}^{3}$ of fuel. The divergence between the obtained results and the results presented in other publications confirm the complexity of the problem and the influence of many factors on the final result. Thus far, none of these factors were considered simultaneously.

Like fuel consumption, exhaust emissions were determined for individual stages as well (Table 3). The exhaust emissions from the logging operations (transport not included) were investigated by Athanassiadis (2000). According to his calculations, the emission of individual exhaust components was: $\mathrm{CO}-37.33 \mathrm{~g} / \mathrm{m}^{3}, \mathrm{HC}-8.03 \mathrm{~g} /$ $\mathrm{m}^{3}, \quad \mathrm{NO}_{\mathrm{x}}-70.48 \mathrm{~g} / \mathrm{m}^{3}, \mathrm{PM}-5.83 \mathrm{~g} / \mathrm{m}^{3}$. The emission presented in this paper is lower. The differences most likely result from the fact that Athanassiadis (2000), rather than direct measurements, used the emission factors from the literature. The reason for lower emissions may also be the fact that a machine of newer generation was used for the tests.
The energy demand for timber transport by a truck depends mainly on the distance covered by the truck. It is usually a distance of several to several $100 \mathrm{~km}$, which is why the measurement results were referred to $1 \mathrm{~km}$ of covered distance. The results are, thus, more universal (Fig. 3). In the discussed investigations the fuel consumption of the truck was $0.023\left(\mathrm{dm}^{3} / \mathrm{m}^{3} / \mathrm{km}\right.$ with the emission of $\mathrm{CO}_{2}$ on the level of $\left.61.53\left(\mathrm{~g} / \mathrm{m}^{3} / \mathrm{km}\right)\right)$. Referring the results to the road conditions, the fuel consumption of the truck was $0.371 \mathrm{dm}^{3} / \mathrm{km}$ and the emissions of $\mathrm{CO}_{2}$ $988.47 \mathrm{~g} / \mathrm{km}$.

In light of the growing interest in the measurement of exhaust emissions under actual conditions of operation, a comparison of exhaust emissions with the admissible limits in the homologation procedure appears interesting. For diesel engines, the emission of $\mathrm{PM}$ and $\mathrm{NO}_{\mathrm{x}}$ is of key importance, and the reduction of these emissions is the most difficult. Tests performed under actual conditions of operation are not yet included in the non-road vehicle homologation procedure in Europe. A pilot program is still underway and the final version of legislation is being prepared (Draft Proposal 2013). In the USA, such tests are already performed for some categories of vehicles and the admissible emission limits in the tests are determined as a multiple (compliance factor) of the admissible limits for laboratory tests. For the tested harvester and forwarder, the emission of PM under actual conditions of operation exceeds the emission limits 2.13 and 1.53 times, respectively, while the emission of $\mathrm{NO}_{\mathrm{x}}+\mathrm{HC}$ for the harvester is greater by more than $50 \%$ (Fig. 4). What is characteristic is that the emission of $\mathrm{CO}$ for both machines under actual conditions of operation is much smaller than the admissible limits. For the forest truck, the emission of $\mathrm{PM}$ and $\mathrm{NO}_{\mathrm{x}}$ under actual conditions of operation is greater than the admissible limits (Fig. 5). The vehicles analyzed in the paper were not subject to exhaust emission tests under actual conditions of operation in the homologation procedure. The then procedures did not provide for this type of measurements. The presented comparison, however, is interesting as it provides a view on the actual emission and shows how it differs from the admissible limits. It is also an 


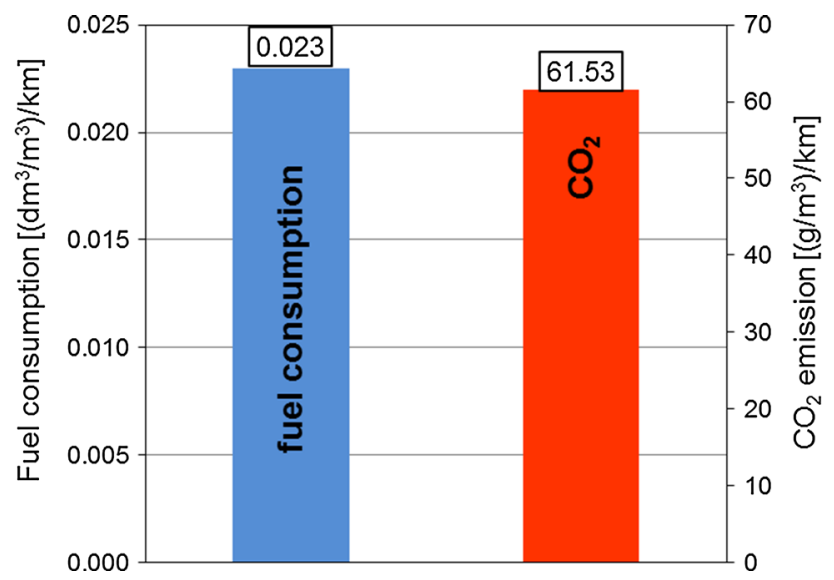

Fig. 3 Fuel consumption and emission of $\mathrm{CO}_{2}$ during transport referred to $1 \mathrm{~m}^{3}$ of timber and $1 \mathrm{~km}$ of covered distance

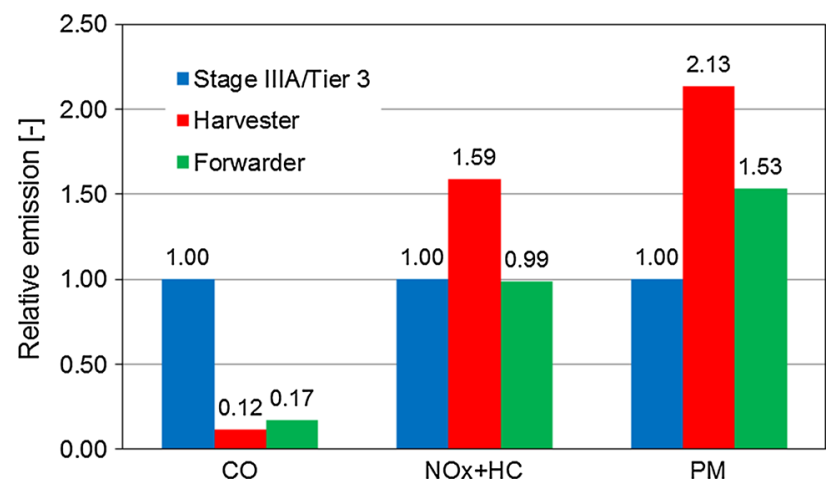

Fig. 4 Comparison of the exhaust emissions from the harvester and forwarder with the admissible limits

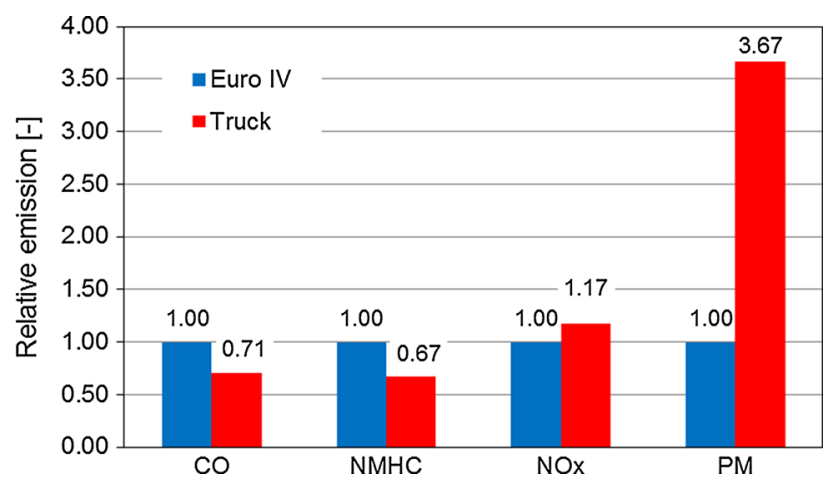

Fig. 5 Comparison of the exhaust emissions from the truck with the admissible limits

argument speaking for the implementation of real driving emission tests in the homologation procedure.

\section{Conclusions}

The summary of the investigations and their analysis confirms the validity of the method of measurement under actual conditions of operation using the PEMS equipment.
The selected measurement method allowed a very accurate determination of the fuel consumption and exhaust emissions from the forest machinery during forest operations and transport to the lumberyard. These are some of the first investigations ever, utilizing the PEMS equipment, and, it is to be stressed that this method creates a great research potential and should be used for further research of forest machinery in operation. In the future, the authors plan to extend their research to other machines and different types of forests, as well as investigate not only the particle mass but also its number and size distribution. Based on the performed investigations and analyses, it has been observed that the greatest fuel consumption in the entire process of timber acquisition is generated by the operation of the harvester. The share of this stage in the process is $38 \%$. It should be added that the results are given for certain conditions under which the tests were performed, e.g., specified length of the truck runs. It is noteworthy that the transport of timber may have a greater share in the process only because it depends on the distance covered by the truck-for greater distances, this stage will most likely have a greater share. The harvester operation also generated the highest emission of $\mathrm{NO}_{\mathrm{x}}$ and $\mathrm{PM}$ - exhaust components that are most problematic for diesel engines. The emission of $\mathrm{CO}$ and $\mathrm{HC}$ was greater for the forwarder. The performed research also confirms that the exhaust emissions under actual conditions of operation significantly deviate from the emissions of the homologation tests, which is why it is fully justified to apply this method in the homologation procedure. The conditions of the currently applicable homologation procedure are not representative of real operation; therefore, such procedure should be changed. In the future, homologation tests should be conducted under actual operating conditions or under conditions that reflect actual work in a better way.

Acknowledgements The research was financed by the National Centre for Research and Development, research project within the Applied Research Programme (Contract No. PBS1/A6/26/2015).

Open Access This article is distributed under the terms of the Creative Commons Attribution 4.0 International License (http://crea tivecommons.org/licenses/by/4.0/), which permits unrestricted use, distribution, and reproduction in any medium, provided you give appropriate credit to the original author(s) and the source, provide a link to the Creative Commons license, and indicate if changes were made.

\section{References}

Anon (2013) Forestry 2013 - statistical information and elaboration. Polish Central Statistical Office, Warsaw

Athanassiadis D (2000) Energy consumption and exhaust emissions in mechanized timber harvesting operations in Sweden. Sci Total Environ 255:135-143 
Attfield M, Schleiff P, Lubin J et al (2012) The diesel exhaust in miners study: a cohort mortality study with emphasis on lung cancer. J Natl Cancer Inst 104(11):869-883

Berg S, Karjalainen T (2003) Comparison of greenhouse gas emission from forest operations in Finland and Sweden. Forestry 76(3):271-284

Berg S, Lindholm EL (2005) Energy use and environmental impacts of forest operations in Sweden. J Clean Prod 13(2005):33-42

De Vries W, Klapp JM, Erisman JW (2000a) Effects of environmental stress on forest clown condition in Europe. Part I: hypotheses and apporoach to the study. Water Air Soil Poll 119:317-333

De Vries W, Reinds GJ, Klapp JM, Van Leeuwen EP, Erisman JW (2000b) Effects of environmental stress on forest clown condition in Europe. Part III: estimation of critical deposition and concentration levels and their exceedancens. Water Air Soil Poll 119:363-386

Dias AC, Arroja L, Capela I (2007) Carbon dioxide emissions from forest operations in Portuguese eucalypt and maritime pine stands. Scand J For Res 22(5):422-432. doi:10.1080/ 02827580701582692

Draft Proposal (2013) In-servive conformity procedure for nonroad mobile machinery - the draft test procedure applies to variable speed engines of categories Q and R (56 to $560 \mathrm{~kW}$ ) of directive 97/68/EC. Online document: https://circabc.europa.eu/sd/d/ 9e89d58f-97c5-415c-868f-9115e2d4886c/Draft_ISC_Proc_\% 20NRMM-PEMS.docx. Accessed 10 Apr 2013

Engel AM, Wegener J, Lange M (2012) Greenhouse gas emissions of two mechanised wood harvesting methods in comparison with the use of draft horses for logging. Eur J For Res 131:1139-1149

Environmental Protection Agency (2002) Health assessment document for diesel engine exhaust. Online document: http://ofmpub. epa.gov/eims/eimscomm.getfile?p_download_id=36319. Accessed 15 Dec 2015

Giannelli RA, Fulper C, Hart C et al (2010) In-use emissions from non-road equipment for EPA emissions inventory modeling (MOVES). Society of Automotive Engineers, Paper 2010-011952

Holzleitner F, Kanzian Ch, Stampfer K (2011) Analyzing time and fuel consumption in road transport of round wood with an onboard fleet manager. Eur J For Res 130:293-301

Johansson J (1996) Case studies on farm tractors as base machines for single-grip thinnings harvester heads. Forestry 69(3):230-244

Karim J (2013) Improving flow rate exhaust measurement when utilizing "small" PEMS. 2013 PEMS Conference and Workshop University of California, Riverside, 11 April 2013

Karjalainen T, Asikainen A (1996) Greenhouse gas emissions from the use of primary energy in forest operations and long-distance transportation of timber in Finland. Forestry 69(3):216-228

Karjalainen T, Zimmer B, Berg S, et al (2001) Energy, carbon and other material flows in the life cycle assessment of forest and forest products. Achievements of the working group 1 of the COST action E9. European Forest Institute, Torikatu 34, Finland. ISBN 952-9844-92-1, ISSN 1455-6936. Online document http://www.efi.int/files/attachments/dp_10.pdf. Accessed 2 Nov 2015

Kheifets L (2012) Epidemiologic studies of ELF and their contribution to risk assessment. 24th Annual Meeting of the Bioelectromagnetics Society, Quebec 23-27 June 2002
Klvac R, Skoupy A (2009) Characteristic fuel consumption and exhaust emissions in fully mechanized logging operations. J For Res 14(6):328-334

Klvac R, Ward S, Owende P, Lyons J (2003) Energy audit of wood harvesting systems. Scand J For Res 18(2):176-183. doi:10. 1080/02827580310003759

Klvac R, Fischer R, Skoupy A (2012) Energy use of and emissions from the operation phase of a medium distance cableway system. Croat J For Eng 33(2012):79-88

Lee DW (2013) Innovative PEMS testing approaches used by TTI. In: 2013 PEMS Conference and Workshop, University of California, Riverside 11 April 2013

Lijewski P, Merkisz J, Fuć P (2013) Research of exhaust emissions from harvester diesel engine with the use of portable emission measurement system. Croat J For Eng 34(1):113-122

Lindholm EL, Berg S (2005) Energy requirement and environmental impact in timber transport. Scand J For Res 20(2):184-191. doi:10.1080/02827580510008329

Lindholm EL, Berg S, Hansson PA (2010) Energy efficiency and the environmental impact of harvesting stumps and logging residues. Eur J For Res 129:1223-1235

Merkisz J, Pielecha J, Radzimirski S (2014) New Trends in Emission Control in the European Union. Springer Tracts on Transportation and Traffic, Vol. 4 2014, ISBN: 978-3-319-02704-3 (Print) 978-3-319-02705-0 (Online)

Metz N (2003) Diesel particulate matter criteria for evaluation of health effects. 24th Internationales Wiener Motorensymposium, 15-15 Mai 2003 Wien

Nordfjell T, Athanassiadis D, Talbot B (2003) Fuel consumption in forwarders. Int J For Eng 14(2):11-20

Oberscheider M, Zazgornik J, Henriksen KB et al (2013) Minimizing driving and greenhouse gas emissions in timber transport with a near-exact solution approach. Scand J For Res 28(5):493-506. doi:10.1080/02827581.2012.758309

Press Release No 213 (2012) IARC: diesel engine exhaust carcinogenic. Online document https://www.iarc.fr/en/media-centre/pr/ 2012/pdfs/pr213_E.pdf. Accessed 12 June 2012

Räisänen J, Hansson U, Ullerstig A et al (2004) European climate in the late twenty-first century: regional simulations with two driving global models and two forcing scenarios. Clim Dyn 22:13-31

Silverman DT, Samanic CM, Lubin JH et al (2012) The diesel exhaust in miners study: a nested case-control study of lung cancer and diesel exhaust. J Natl Cancer Inst 104(11):855-868

Szpojda B (2013) 60\% harwesterem? To możliwe (Eng. 60\% by harvester? It is possible). Las Polski 17:10-11

Vermeulen R, Silverman DT, Garshick E et al (2014) Exposureresponse estimates for diesel engine exhaust and lung cancer mortality based on data from three occupational cohorts. Environ Health Perspect 122(2):172-177

White J, Khalek I, Bougher T, et al (2010) Report no 03.14936.12, PM-PEMS measurement allowance determination. US Environmental Protection Agency, California Air Resources Board and Engine Manufactures Association. Online document: http:// www.epa.gov/otaq/regs/hd-hwy/inuse/420r10902.pdf. Accessed 15 Dec 2015 